\title{
The Impact of American Oil Company's Existence on the Sakai Community In Riau Province
}

\author{
Agus Setiawan \\ \{a_setiawan55@hotmail.com\} \\ History Department Faculty of Humanities Universitas Indonesia \\ Gedung III. Lt. 3 Fakultas Ilmu Pengetahuan Budaya Universitas Indonesia \\ Depok 16424
}

\begin{abstract}
This paper focuses on the influence of the existence of foreign oil companies that has been operating in the territory of the Sakai Tribe as one of indigenous tribes in Riau. Sakai tribe has inhabited the area which later became the oil mining area of PT. Chevron Pacific Indonesia (PT CPI). Oil mining undertaken in Riau contributes to environmental changes including in the areas where the Sakai people live. The environmental changes also change the pattern of society activity and character because of some changes in terms of patterns of working and settlements. This research uses historical method where historical sources are also obtained through interview with people of Sakai tribe and PT.CPI officers. The results of the research show the existence of environmental pollution caused by mining activities and it also influences on social mobility among members of Sakai community.
\end{abstract}

Keywords: Mining Act, Oil Company, Oil Exploration, Pollution, Sakai Tribe

\section{Introduction}

Before World War I oil had replaced the role of coal as a major energy source of the world. Oil was the main target of industrialized countries to meet the energy they needed to run their industries. In the middle of the competition for oil among industrialized countries, World War I took place in Europe. The oil company's partisanship to those that fought in World War I and World War II became the determinant factor of the Allies victory in the two World Wars. Oil was the most important energy since the early twentieth century until the present day because oil was the main fuel to power industrial machines in large quantities besides it was also necessary to operationalize the war machines especially during The World War I and The World War II.

Some oil drilling companies also had competed to get larger marketing area in order to gain as much profit as possible. In Indonesia, or during the Dutch colonial rule precisely, oil has been begun to be exploited by Dutch and American oil companies. A number of foreign oil companies are even continuing their mining activities after Indonesia's independence. At this point the operational area of the mining area became wider, especially after the issuance of the Foreign Investment Act in 1967. However, the wider the mining area, the greater the impact 
on environmental damage. Social problems later arose because the damaged environment was home to indigenous tribes that had inhabited the area for years.

Research on the existence and mining activities of foreign oil companies has been written. However, until now, academic research on the history of infrastructure and environment as the impact of oil exploration in Indonesia has not been done. Environmental changes and infrastructure development in Indonesia, especially in Langkat, Cepu and some areas in Riau as the first areas where the oil exploration were conducted in the colonial period until now has been contributing to the local government income, however the local people economic growth have not changed much. Such conditions increase some important research questions regarding the existence and empowerment of communities living around the oil exploration.

Related to the existence of oil exploration, does the government both in colonial times and in the independence period as well as government and private oil companies pay close attention to the fate and livelihoods of communities around oil exploration areas? How about the reaction of the surrounding communities especially Sakai people related to oil exploration that certainly changes the environmental situation where they live?

\section{Method}

This research uses the historical method which consists of four stages namely heuristic, verification, interpretation and historiography. The heuristic stage is data collection carried out at the National Archives of the Republic of Indonesia, National Library, Regional Library of Riau Province in Pekanbaru, PT. Chevron Pacific Indonesia (CPI) and the Siak Sultanate Museum. The data collection was carried out in January to June 2018 and succeeded in finding various information and documents related to the oil mining industry in Riau, especially oil mining activities in the Riau region. In addition, research in a number of these libraries also found information about empowerment programs for local communities conducted by PT. CPI.

Data collection was also carried out by interviewing a number of people including the manager of PT. CPI, oil mining workers in a company that is a partner of PT. CPI, Chairperson of the Sakai Tribe in Batin Sebanga, owners of oil palm lands whose land is contaminated with oil mining waste and community members who live around the mining area. A number of interviews were conducted during fieldwork in Pekanbaru, Siak, Duri and Dumai in May and June 2018. Through these interviews, this study obtained information on the current conditions regarding mining activities carried out by PT. CPI and environmental conditions due to oil mining activities. In addition, the impact of oil mining activities on socioeconomic conditions was also obtained through direct field observations in Duri Subdistrict and Dumai City.

\section{Results and Discussions}

Riau is one of the provinces in Indonesia that is rich of natural resources, especially mining and marine fisheries. The geographic situation of Riau Province is special, because the province consists of many islands (3,214 islands) with extensive waters. Etymologically, the 
word Riau itself comes from Portuguese, Rio, which means river. Following its history, the origin of the discovery of Riau itself can be obtained from various folktales in various versions. One of them that can approach the truth is that the word 'Riau' comes from the word Riuh which means crowded. In the sixteenth century when residents and merchants met in the ocean, they always said "going to Riuh." They pointed towards a crowded place among the Bintan islands. Eventually this continued, until finally there was a change in sound, which was previously 'Riuh' became 'Riau'. This country in its history then continued to grow rapidly as a trading market that was crowded by traders to sell marine products and surrounding forests [Ridwan, M. 1999].

In the previous source itself, the name Riau was first referred to in writing in the Malay text, entitled Memorial of the History of Johor. In the text it is stated that Sultan Abdul Djalil Syah ordered his fleet to go to Bintan to make the country on the Carang river, which was later called a person by the name "Riau". Since then, the name Riau has become known by the people around it. Referring to this statement, this fits into the colonial record written by Governor Bort in Malacca in 1673 which stated that he had received a letter from Admiral Tun Abdul Djamil from Johor who told him that he had gone to Bintan Island to protect the island and equip the ships that are there [Kratz 1973, 43]. Based on that, the name Riau is then relevant to a river that flows from the West towards the present city of Tanjung Pinang. The place was indeed a place of trade activity, as well as a center of empire and defense in the sixteenth century until the nineteenth century [Ridwan M. 1999].

Administratively, Riau province consists of one municipality, five districts, one administrative municipality and two administrative cities with 78 sub-districts and 1,142 villages or kelurahan. The waters of this province, including the Exclusive Economic Zone (EEZ), are estimated to reach around 379,000 km2. The boundaries of Riau Province when viewed from its position with other provinces are in the north bordering the Malacca Strait and North Sumatra Province, on the south bordering Jambi Province and West Sumatra Province, on the east bordering the Riau Islands Province and the Malacca Strait, while in the West it borders the Provinces of West Sumatra and North Sumatra. The specificity that is the location of this province is because the province is directly adjacent to neighboring countries (Singapore and Malaysia) and is directly confronted with international waters (the Malacca Strait), which has very heavy traffic. The land area is $94,562 \mathrm{~km} 2$ which stretches from the slopes of Bukit Barisan to the Malacca Strait. which means it ranks the second largest compared to other provinces on the island of Sumatra [Manuwoto 1996]. 


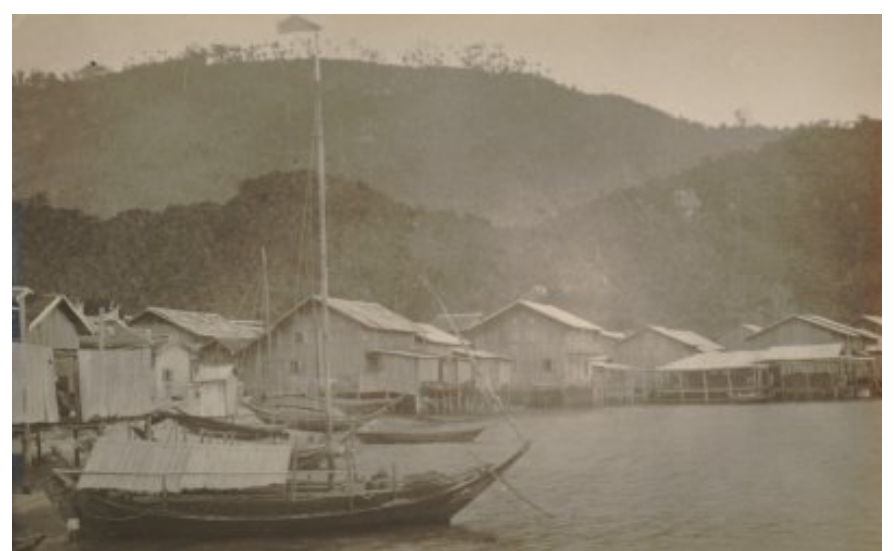

Figure 1. (Photo: Late-colonial beach in Riau, KITLV Collection)

Riau Province which has large land is a province that has rather typical conditions compared to other Indonesian provinces. Its existence extends from the slopes of Bukit Barisan to the Straits of Malacca and is astronomically located between $01^{\circ} 05$ '00 "South Latitude $-02^{\circ} 25^{\prime}$ $00^{\prime \prime}$ North Latitude or between $100^{\circ} 00$ '00 "- $105^{\circ} 05^{\prime} 00$ "East Longitude. The spread of land in this province is divided into two, namely the landscape which is the eastern part of the island of Sumatra and the islands bordering neighboring countries namely Malaysia and Singapore. About 80 percent of Riau province is waters. Parts of the land are scattered with different heights, ranging from sea level to above $1000 \mathrm{~m}$ above sea level with slope ranging from land to very steep ( $>45$ percent). Based on its physiography, the land in Riau Province consists of plains (floodplains, coastal plains, deltas and others) which are located in the eastern part of Riau province, the hills which are scattered towards the island of Sumatra and covered with mountains which are included in the Bukit Barisan mountain range. In this area found land with an altitude of more than $1000 \mathrm{~m}$ which is in the area of Kampar Regency. The climate of Riau Province is included in a wet tropical climate which has rainfall between 1500 - $3000 \mathrm{~mm} /$ year, with high temperatures and humidity throughout the year. Based on agroclimate clarification. Riau Province is mostly included in type B climate. Based on the distribution of its land, in Riau Province in general there was land from mineral materials (mineral soil) covering an area of 5,153,217 ha and organic soil (peat) with a thickness of $>100 \mathrm{~cm}$ covering 4,302,943 ha. With the existence of land resources that have a wide range of soil properties, the agricultural development in this region has broad consequences, both in terms of the variety of plants developed and managed [Manuwoto 1996].

In the economic sector, Riau province is one of the country's largest foreign exchange earners, especially in the oil sector with a production of more than 600,000 barrels per day (around 60 percent of total national oil and natural gas production). Besides oil and gas, Riau is also rich in natural resource potential in the form of forest products, agriculture, plantations, various mines and minerals and marine products (fisheries). In the economic structure of Riau itself, there are three sectors that make a considerable contribution, namely: agriculture, industry and trade. The contribution of these three sectors is significant to the existing development in Riau province with a total achievement of 80.93 percent (2005 data), and is expected to reach a higher level for its establishment [Erlangga 2007, 39].

In terms of its own social culture, Riau is known for its high level of ethnic heterogeneity. In 
addition to the native population (Riau Malay tribe), the other ethnic groups that are also quite dominant are Minangkabau, Batak, Javanese, and Chinese. The high level of immigration to the province is one of the main factors in the diversity of ethnic groups that exist and live in Riau province. Despite the large flow of urbanization, the solidity of the community still appears to be strong enough, this in itself is caused by several factors, including the similarity of religion and cohesiveness among fellow community leaders. The vision statement of Riau as a "Center for Malay Culture" which is synonymous with the religion of Islam, makes the similarity of religion as a binding factor that is important for society at the social and cultural level. In addition, there are similarities in views among community leaders which are divided into 3 (three) pillars, namely traditional leaders (adat institutions), religious leaders (Majelis Ulama Indonesia), and intellectual leaders (incorporated in Riau's intellectual community institutions) in responding to daily activities carried out by the government [Erlangga 2007, 40].

Until now there has been no definitive historical data or evidence and can be used as an academic backing for when minerals and mining activities were first carried out in the archipelago. However, based on several archaeological discoveries, at least in some regions of the archipelago, humans have begun to carry out simple metal and mineral mining activities since the 5th century AD. Other further evidence is found on Bangka Island and is estimated to be an ancient tin mine from the period of the Srivijaya Kingdom's rule of around 600-700 M. Various studies on the possibility of mining activities in the BC period itself have actually been shown various studies related to the discovery of various objects made of metal in the archipelago which is believed to have originated from the period 3000-2000 BC. The Bronze Age in Southeast Asia itself began around 500-200 BC [Bellwood 2007, 268].

Metal mining activities are believed to be growing along with the increasing trade relations between India and China involving the archipelago. Geographically, the archipelago is in the trade route between India and China, coupled with cultural influences including the influence of religion that has developed in the archipelago, namely Hinduism and Buddhism. The development of these two religious influences more or less contributed to the development of metal mining considering both Hindu and Buddhist teachings depicted gods or Buddhists in the form of statues made of stone or metal as objects of worship in temples or monasteries. Both Sriwijaya and Majapahit had ruled the archipelago in the 7th and 14th centuries AD, control of the area which became a source of metals, especially precious metals was one of the priorities [Simbolon 2007, 427]. ${ }^{1}$

Until the arrival of Europeans to the archipelago, especially the Dutch merchants who later formed the VOC trading partnership (Verenigde Oost Indische Compagnie), no single ruler in the archipelago issued a written law to regulate mining activities even though the VOC itself had been involved in tin trading with the sultan the Palembang sultan was even able to monopolize and then take control of trade and tin sources belonging to the Palembang Sultanate on Bangka and Belitung Islands [Tagliacozzo 2011, 28]. ${ }^{2}$

${ }^{1}$ To oversee gold mining in the Upper Batanghari River, King Hayam Wuruk sent Adityawarman in $1347 \mathrm{AD}$ to become a ruler in the Minangkabau region.

2 During the period 1723-1730 the tin that was sent by the Palembang Sultanate from Bangka and Belitung Island to VOC reached 175 tons per year. When contract workers from Guangdong came and started to work in Bangka and Belitung, tin production increased thanks to the more efficient mining methods introduced by the Chinese workers. 
In general, until the beginning of the Dutch colonial era, metal and mineral mining in the archipelago was still traditional because it was only for the daily needs of the community or individuals and mining had not been carried out on a large scale for commercial purposes. This also allows for the absence of a significant impact on environmental changes or the impact that can be caused by mining activities on people living around the mining area.

Commercial mining was only begun by the Dutch along with the discovery of various sources of mining in large quantities. The discovery of various mining material sources is inseparable from the existence of research activities carried out by Dutch scientists who are members of the Dutch Geographical Society (Nederlandsch Aardrijkskundig Genootschap). This association is a scientific professional organization based in Amsterdam and conducts several scientific expeditions and research in the archipelago. The Dutch colonial government itself provides assistance for various research activities that they do. In addition to research carried out by this organization, the Dutch government also conducted rainfall-related mapping and surveys conducted by the Ministry of Marine Affairs [Metzger 1888].

Various results of research on the source of mining goods in the archipelago attracted attention not only to the Dutch Colonial Government but also from private companies which subsequently sought to obtain mining concessions from the colonial government. Mining goods are one of the raw materials that are very much needed especially with the eruption of the Industrial Revolution in England. Western European countries which in fact have colonies in Asia and Africa and South America are competing to obtain sources of raw materials including mining materials and mineral sources for energy purposes.

One source of energy which then plays a very important role in driving industrial machinery is petroleum. The presence of large quantities of petroleum in Titusville, United States, replaces the role of coal as a world energy source that is contested by various forces wherever this energy source is located. In the Netherlands East Indies, oil was found in large quantities in the Langkat region, North Sumatra. The discovery was followed by the discovery of various new oil sources in various regions in the Dutch East Indies including in the Cepu (Central Java), Tarakan and Bunyu regions (East Kalimantan) and Cirebon (West Java).

The new petroleum sources in the Dutch East Indies invited not only Dutch oil companies, but also foreign oil companies from other countries, especially from the United States, to invest in them while expanding their network and business control. The desire of these foreign companies made the Dutch colonial government worried about the dominance of foreign companies in the mining industry in the Indies. To avoid foreign domination, the Dutch colonial government issued the Dutch East Indies Mining Act in 1899. The law, besides being one of the efforts of the Dutch colonial government to regulate mining activities in the Dutch East Indies, was also a political economic maneuver to prevent entry foreign capital which can result in the strengthening of foreign economic dominance.

Oil exploration activities in the area around the city of Cepu and Riau have been carried out by Dutch companies and the United States in the colonial period, but the Dutch colonial government succeeded in reducing the investment of foreign oil companies, especially from the United States, through regulations stipulated in the Dutch East Indies Mining Law or Indische Mijnwet in 1899. Unlike the colonial period even during the Old Order government, 
the New Order government actually invited the entry of foreign oil company investment along with the issuance of the Foreign Investment Law in 1967. The entry of foreign capital is expected to stimulate the economy in the region Even though the oil mining area on the other hand will also have a negative impact on environmental damage. These environmental changes certainly helped to change the pattern of activities and character of the community because of some changes in terms of patterns of work and residence.

The discovery of oil in Telaga Said, Langkat, was a milestone in the commencement of the commercial oil mining era in the Indies. Not only the Dutch oil companies, some foreign oil companies, especially from the United States, were interested to invest their capitals in the Netherlands Indies. Related to the desire of foreign oil companies that wanted to invest in the Dutch Indies, the Dutch colonial government issued the Dutch Indies Mining Law or De Indische Mijnwet in 1899. The law was a legal effort of the Dutch government to withstand the entry of foreign investment, especially from The United States in oil mining sector. This could not be separated from the competition between Dutch and American oil companies to get oil fields in the Dutch Indies.

Thus the Dutch Indies Mining Law itself essentially aimed to limit the involvement of foreign companies other than those originating from the Netherlands in order for the benefits of oil mining concessions to fall only to the colonial government or Dutch private companies. One of the first oil fields in the Dutch Indies was in Pangkalan Brandan that since 1885 was controlled by the Royal Dutch Company and did not change hands to other foreign companies. Even in 1890 it was formed a partnership organization to run oil mining business in North Sumatra. With the legal protection provided by the Dutch colonial government, the Royal Dutch Company was increasingly free to expand its oil mining business. Along with that, new oil wells were discovered even with more oil deposit. To store and to process the petroleum into more specific products, the company needed oil refineries with large capacity based on the size of that period. Royal Dutch Company exploited the calm situation by building oil refineries in Pangkalan Brandan. The refinery was known as the first oil refinery in the Dutch Indies. Processing plants were established near the river for more efficient waterways transportation. The people of Pangkalan Brandan who work for the oil companies usually carried a variety of processed petroleum products that had been packed in large cardboard boxes to the boats by the river. Near the river was also established a kind of dormitory and settlement for the factory workers so that the distance between where they worked and their houses became closer. In addition to waterways, transportation to the banks of the river was also conducted by train. The railway was built specifically for use as a means of transporting oil processed products. In its development, the company also built an oil pipeline which connected Perlak in Aceh to Pangkalan Brandan in 1901 [Verslag Over 1900, 1901:25].

This policy was an attempt of the Dutch colonial government to improve the economic and social life of the indigenous population and at the same time the colonial government tried to erase previous exploitative economic policies. The issuance of the ethical political policy was inseparable from the pressure of the socialist group in the Dutch parliament that called for the improvement of the lives of indigenous peoples who had suffered so much when at the same time the Dutch capitalists got much profits from various businesses in the colonies. The pressure of the socialist group continued until the publication of the new Indies Mining Act in 1913. The publication of the act essentially gave the colonial government greater authority to manage mining activities in the Indies. 
Until the outbreak of the Pacific War, Dutch and American private oil companies dominated oil mining activities in the Dutch Indies as more oil resources were found mainly in South and Central Sumatra. Oil exploration and exploitation in South and Central Sumatra reached its peak when the oil potential areas were occupied by Japanese forces during the Pacific War (1942-1945). In the region of Riau, Japanese troops managed to find some new oil production centers, especially Minas well 1 that have been producing until now. For the purposes of exploitation, the Japanese occupation government recalled the experts who had previously worked in several oil fields in Sumatra after previously examining the various records owned by American oil company namely Caltex. Not only the records, according to a Japanese oil expert who participated in drilling activities in Minas, Riau, Toru Oki, the ease of drilling was also inseparable from the equipment left by Caltex during the Japanese invasion of the region [Jasjfi 1985, 65]. Drilling locations in Minas were also easily accessible and it made easier for workers and to transport the necessary tools for drilling. Since then, the commercial oil drilling in Riau had entered a new era which further affected the life of the people in the Riau region. Along with that, the consumption of petroleum in Indonesia also increases from year to year. Increasing oil demand will affect efforts to expand areas that have potential oil deposits as well as potential for widespread environmental damage due to mining activities.

Table 1. Oil Consumption in Indonesia in million barrel (2005-2015)

\begin{tabular}{|l|l|l|l|l|l|l|l|l|l|l|}
\hline 2005 & 2006 & 2007 & 2008 & 2009 & 2010 & 2011 & 2012 & 2013 & 2014 & 2015 \\
\hline 1,303 & 1,244 & 1,318 & 1,287 & 1,297 & 1,402 & 1,589 & 1,631 & 1,643 & 1,676 & 1,628 \\
\hline
\end{tabular}

People who live in oil mining areas in Minas and Duri or generally in the Riau region prior to oil exploration was conducted on a large scale, were more to work in the plantation and agricultural sectors. The local people further interacted with the migrants who were mostly planters whom were imported from Java and China for cheap wages. The livelihoods of the people who live in Riau increasingly stretched along with the opening of oil mines after some new concession were signed. The private oil companies generally recruit locals to work in oil drilling centers as crude as pushing tools to drill the ground.

In addition, the company also recruited locals to work as porters in petroleum processing centers processed into various processed oil products to be shipped to other parts of the Netherlands East Indies or exported abroad. But so far, the most beneficiaries of petroleum exploration in Riau are private oil companies from the Netherlands and the United States. The American oil company, NPPM which later turned into Caltex and then changed again to Chevron in 2007, which became an oil drilling operator in Minas, for example, not only gained favorable concessions from the Dutch colonial government but also received protection from the Dutch colonial government to conduct oil mining activities.

When Indonesia gained the independence, the existence of national and foreign oil companies continued its oil mining activities in the Minas and Duri regions. Partly due to obtaining new concessions from the Indonesian government especially since the issuance of the Foreign Investment Act in 1967 which resulted in the flow of foreign capital to Indonesia including in the mining sector. This condition in the end gave birth to a contradiction when the effects of 
mining began to be seen in the early 2000 s, especially when viewed from the social and economic side. A contradictory view is visible visible where the local community including the Sakai community just become the marginalized not only from the economic and social but also in the physical sense. This is because the encroachment of forests for expansion of oil mining activities makes their presence also marginalized. The Sakai tribe is an indigenous tribe living in the forests of Riau.

The Sakai tribe is one of the indigenous tribes in Riau Province that has inhabited the area which is now a place of oil mining by several foreign oil companies since the colonial period. Since the colonial period, a number of foreign companies have obtained oil concessions from the Dutch colonial government and then in the independence period to get concessions from the Indonesian government to conduct exploration and exploitation in Riau. Along with that the opening of new oil fields which also means opening new areas for oil mining activities further erode the existence of forests in the Riau region. Among these forests are the residence of the Sakai Tribe that has long inhabited the area so that forest encroachment becomes a crucial point for the Sakai people because it makes them have to step aside and think of their next place to live.

Some members of the Sakai community strive to survive in their changing neighborhood, but there are also some who are trying to adapt to a new environment that is to live in residential areas around Duri City along with other communities. For the Sakai people living and living together with other tribal communities in urban areas is a challenge in itself considering that they generally live in forest areas that seem alienated from urban life.

The challenges faced by the Sakai community in urban areas vary from job to customary problems that sometimes require adjustments to urban mobility that require one to make the most of the time as efficiently as possible. In addition, the Sakai community skill problem that wants to work in urban areas also becomes another challenge that must be answered. Until now, there are enough members of the Sakai community who have completed education at the college level and are able to compete in getting jobs. Nevertheless, the whole Sakai community is required to be able to raise their level of education and skill to increase their competitiveness.

Oil mining activities conducted by foreign private oil companies in Riau, especially CPI, provide great benefits to the company mainly due to the availability of high quality oil sources and the use of modern technology in mining and oil processing. The big profits should be enjoyed by the people of Riau especially those living around the oil fields because they are directly affected by the impact of the existence of CPI oil fields. To help improving the people welfare of Riau, PT. CPI makes various community empowerment programs including educational programs to improve the quality of human resources in Riau.

PT. The CPI regards education and training as a long-term investment that contributes to local development and can enhance constructive relationships between companies and surrounding communities. When Caltex was named, the company began to pay attention to the education sector with the establishment of SMAN 1 in Pekanbaru in 1957 and helped to renovate the classrooms in the Rangau River, Pauh-Libo, Pematang Pudu, Jiat, Rangau Petani and Minas Barat. 
At the college level, PT. CPI established Polytechnic Caltex Riau (PCR) in 2001. Polytechnic is the first polytechnics established in Riau region in cooperation with Riau Province Government. Until now the number of students who are studying in CPR amounted to 1600 students. In addition to the establishment of educational institutions CPI also provides a scholarship named Darmasiswa Chevron Riau (DCR). This scholarship is aimed at helping gifted high school students to continue their education at university level. Another program in education is to set up vocational training for young people and drop out students. This program is implemented not only in Riau Province but also in East Kalimantan and West Java.

In addition to the education sector, the CPI also gives attention to the small businesses of society to improve the social and economic life where there are CPI operations. To create sustainable livelihoods through small and micro businesses, CPI offers the Local Business Development (LBD) program which was launched in 2001. This program is aimed at helping small companies and cooperatives in Riau, East Kalimantan and West Java. The scheme is intended to help communities in CPI operating areas to become competent, professional and reliable suppliers of goods and services while at the same time promoting regional economic growth.

In addition to supporting local businesses, CPI also encourages various entrepreneurs including in order to preserve local heritage and traditions such as supporting the traditional art woven preservation program that produces beautiful Malay cloth. The CPI provides training and donations of 12 looms following building a center and a weaving gallery. CPI also provides Batik Riau training starting from August to October 2012. Participants of this training are housewives and young women drop out from 11 urban villages in Rumbai and Rumbai Pesisir Subdistrict, Pekanbaru City, Riau. They are introduced and trained using batik tools and techniques, coloring techniques and washing. In the next stage which was held in June 2013, participants are equipped with post-production skills so that the batik produced has a high selling value.

It can not be denied that the various oil mining activities conducted in Riau Province by the national oil companies and foreign oil companies have changed the geographical features of Riau Province as well as contributing to environmental pollution. Oil mining conducted by US oil company NKPM (Nederlandse Koloniale Petroleum Maatschappij) in the colonial period and continued by PT. Caltex and later PT.CPI in the independence period have contributed to the increasing economy of communities around the oil mining activities, especially in the areas of Rumbai, Duri and Dumai. In all three areas, the existence of PT. The CPI and its activities provide so much impact for the surrounding community both positive and negative impacts including the impact on the environment. On the other hand, foreign oil companies recognize that the sustainability of their existence in a region is also inseparable from the acceptance of the surrounding community, so there should be a mutually beneficial relationship, especially towards the end of the New Order government. Toward the transition of government into the Reform Order, people began to question various cases as a result of mining activities during the New Order government as a taboo to protest.

Through various programs that can maintain its presence in Riau, PT. Chevron Pacific Indonesia (CPI) seeks to improve relations with the people of Riau, especially those living in oil mining areas. Based on various information collected by researchers either through interviews with local communities including those working at PT. CPI and its subsidiaries, 
literature sources from various libraries and field observations and brochures and leaflets published by PT.CPI, various programs have been launched and run by PT. CPI to support improving the quality of life of surrounding communities including efforts to improve the quality of human resources. According to Manager of PT. Chevron Pacific Indonesia (PT CPI) based in Rumbai, Pekanbaru, Mr. Deswandi, since the beginning of existence of PT. The CPI formerly named Caltex has contributed to the economic progress of the people of Riau both directly and indirectly. In the infrastructure sector, the company has built roads connecting Dumai and Pekanbaru. Although the road built is a requirement for the company to be able to send oil mines to oil refineries located in Dumai Port, yet another impact that arises is the increased flow of goods and services in the region. In addition, various trading centers appear along the way because the road is also intended for the community in running an increasingly crowded economic activity. On the other hand, however, the impacts of forest destruction around the mining area continue to occur and this directly touches the living and dwelling communities by utilizing forest products.

In addition to efforts made by PT. CPI to improve the social and economic life of the people of Riau, there are also various complaints made by some parties related to the existence of the oil fields. It is undeniable that the existence of various operations related to oil mining activities has a significant impact on the environment in Riau including the contamination of ground water and rivers in some areas in Riau. This condition also affects the lives of indigenous tribes living in Riau, including the Sakai tribe who rely on their livelihood by catching fish in the river. With pollution of their rivers due to the impact of oil mining waste, their fish catches are much reduced. This is because the death of river microorganisms such as plankton into fish food. In addition, fish consumed by the Sakai community are also at risk of being polluted by oil mining waste so they can endanger their lives.

In addition to complaining about the diminishing of fish in the river, Sakai people in Bengkalis, Riau also complained of the smell of rotting pollution caused by the river Batang Pudu. The demonstration conducted by the Sakai community on May 27, 2007 was directed against PT. Chevron Pasific Indonesia (CPI) is suspected to have disposed of waste oil processing plants. Sakai Chief of Sakai in Bengkalis, Bathin Matan, ultimately wants a peaceful effort with the CPI with some of the conditions such as for Sakai children to work in PT. CPI in addition to asking for compensation for the waste they dispose into the River Batang Pudu for the last two years. Demonstrations conducted by the Sakai people themselves are inseparable from the economic disparities that occur between CPI workers and local residents.

In addition to environmental pollution and economic disparities, another problem that often triggers the tension between society and oil miner companies is the problem of land use over the existence of indigenous tribes in Riau. They seemed pressured by the expansion of the oil company's operating areas until some were forced to move to other areas as well as leaving the area that they and their parents have lived for so long. Riau Regional Government itself has been trying to anticipate various problems that can trigger disputes between the surrounding community with the company but the surrounding community suspects the existence of regional government alignments to foreign oil companies as in the case of river pollution due to disposal of waste oil processing plants. In Duri precisely in an environment close to oil refineries, community leaders have even brought environmental pollution cases to Jakarta but did not get the best solution and the case has not been resolved. 


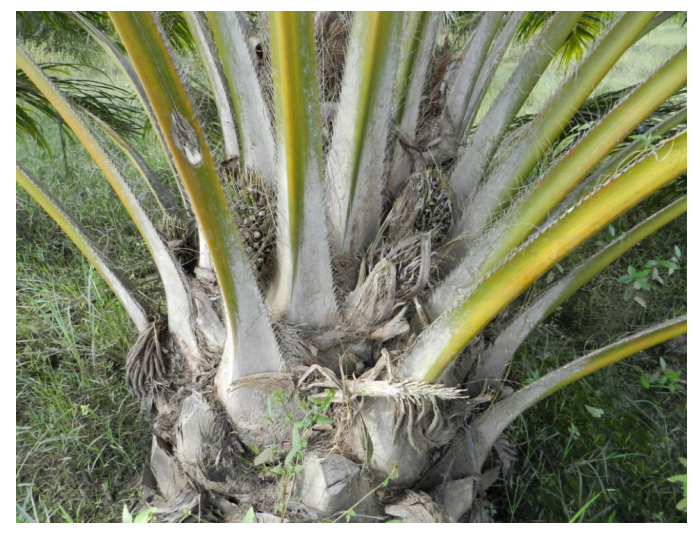

Figure 2. Oil palm plants contaminated with oil mining waste of PT. CPI. It appears that the oil palm fruit is black and dry so it cannot be harvested (Duri Riau, July 24, 2017)

\section{Conclusion}

The presence of oil companies and their mining activities has both negative and positive effects. What has been done by foreign oil companies in Riau, especially PT. CPI is a form of empowerment of surrounding communities including efforts to improve the quality of human resources, which until now has been perceived benefits by surrounding communities. In many brochures published by PT. CPI shows the number of community empowerment activities around by companies to improve the economy of the community. Various recognition of community leaders and students who get scholarship from PT. The CPI shows all the positive aspects of the existence of foreign oil companies and the community empowerment programs that have been running. Environmental pollution conducted by PT. CPI even seemed to disappear along with the brochure on clean water treatment facility in Duri. The brochure is even accompanied by the facts surrounding the water treatment facility that is clearly contrary to the conditions of the Sakai Tribe who protest against river pollution and result in the destruction of ecology and natural balance in Duri area.

On the other hand, the negative impacts arising from oil mining activities in some areas of Riau are groundwater contamination and reduced natural balance. In the Duri area the level of ground water pollution has even started to be feared by the residents around the activities of mining and oil processing. In the Duri region there are areas where the color of the groundwater has changed colour yellowish so it is not feasible to be used for bathing let alone consumed. Social inequality is also a problem that can be erupted at times, especially if there is no attempt to defuse the situation. Both impacts should be the attention of all parties, especially the Regional Government of Riau and PT. CPI that holds various decisions because the surrounding community can be said is a new passive party will react if there are things that are considered harmful to them. Until now the existence of foreign companies is still a pro and cons in the community. For those who get a lot of benefits with the presence of oil in Riau would be a community group that supports the existence of oil companies and all its activities. But people living in oil mining and processing areas as well as experiencing direct impacts of environmental pollution and affecting their health levels are disadvantaged groups due to the existence of oil companies. They deserve attention because it is a disadvantaged group 


\section{References}

[1] Allen, GC. 2003. Western Enterprise in Indonesia and Malaya A Study in Economic Development, London: Routledge.

[2] Giddens, Anthony. 2010. Teori Strukturasi Dasar-dasar Pembentukan Struktur Sosial Masyarakat, Yogyakarta: Pustaka Pelajar.

[3] Gouda, Frances. 2007. Dutch Culture Overseas: Praktik Kolonial di Hindia Belanda 1900 - 1942, Jakarta: Serambi.

[4] Delaisi, Francis.1922. Oil: Its Influence on Politics, London: The Labour Publishing Company Ltd.

[5] Erlangga, 2007. Efek Pencemaran Perairan Sungai Kampar di Provinsi Riau terhadap Ikan Baung (Hemibagrus nemurus). Laporan Penelitian

[6] Ismail, Taufiq (Ed). 1997. Pertamina Dari Puing-puing ke Masa Depan 1957-1997, Jakarta: Hupmas Pertamina Publisher.

[7] Jasjfi, Ir. E, et.al. 1985. Bunga Rampai 100 Tahun Perminyakan Indonesiai, Jakarta: Puslitbang Teknologi Minyak dan Gas Bumi Lemigas.

[8] Koninklijke Nederlandsche Maatschappij Tot Exploitatie van Petroleumbronnen in Nederlandsch Indie. 1901. Verslag Over 1900, 's-Gravenhage: A. Stijhof.

[9] Leirisaa, RZ. 1998. Strukturisme Dalam Ilmu Sejarah (Pengantar), Program Ilmu Sejarah, Program Pascasarjana Universitas Indonesia, Jakarta.

[10] Leirissa, RZ. 1999. Metodologi Strukturis Dalam Ilmu Sejarah, Program Ilmu Sejarah, Program Pascasarjana Universitas Indonesia, Jakarta.

[11] Lloyd, Christoper. 1993. The Structure of History, London: Basil Blackwell.

[12] Manuwoto, Syafrida. 1996. Pembangunan dan Fenomena Kemiskinan Kasus Profil Provinsi Riau, Jakarta: PT Grasindo.

[13] Nederlandsch-Indische Aardolie-Maatschappij. 1921. De Waarheid over Djambi: overzicht van de officieele gegevens betreffende het ontwerp tot oprichting der NederlandschIndische Aardolie-Maatschappij. Amsterdam: De Standaard.

[14] Peter Mellish Reed, "Standard Oil in Indonesia, 1898-1928", The Business History Review Vol. 32 No. 3 (1958).

[15] Rab, Tabrani. 1999. Menuju Riau Berdaulat: Penjarahan Minyak Riau, Yayasan Penerbit Sosial Budaya Riau. 
[16] Ridwan, M. 1999. Riau Lingga Dilema Kekuasaan dan Implikasi Perdagangan 17841824. Thesis, Depok, University of Indonesia. 